\section{Professor Walter F. Colby}

Walter Francis Colby, MBE, PhD, died on July 2 at his Washington residence several weeks after suffering a heart attack at his home in Ann Arbor, Michigan. He would have been 90 years old on July 28 .

Colby, a physicist and musician, travelled widely in many parts of the world. For many years he was the "talent scout" for the physics department of the Univer. sity of Michigan, recruiting faculty members from abroad. He was especially active in inviting outstanding lecturers for the famous Michigan Summer Symposium on Physics, which ran from 1923 to 1941. For several great European physicists their summer at Michigan was their first visit to the United States.

After Colby received his AB degree at Michigan in 1901, he taught piano there in the school of music. $\mathrm{He}$ went to Vienna in 1902 to study with the great piano teacher Theodore Leschetizky. The lectures of Ludwig Boltzmann, however, turned his attention to physics. Returning to Michigan in 1904, he pursued his studies of physics and obtained his $\mathrm{PhD}$ in 1909. He was appointed to the physics faculty and for several years did experimental and theoretical work on the infrared spectra of molecules, a field in which Michigan pioneered under the guidance of the late Harrison M. Randall. This research played an important part in the early development of the quantum theory. In 1912 Colby was on leave in Munich and worked under Arnold Sommerfeld on problems in wave propagation. He spent the following academic year at the Mount Wilson observatory.

During the First World War, Colby did research on aerial photography for the Eastman Kodak Company. In the Second World War he was a key member of the small group investigating the state of German atom bomb research. Though almost 65 years old, he was active in the war zone, sometimes entering places before the allied troops had taken them. His familiarity with languages, roads and laboratories in Europe was of great value in these operations. He was awarded the US Army Medal of Freedom and appointed as an honorary member of the civilian division of the Order of the British Empire.

After the war Colby became the first director of the intelligence division of the US Atomic Energy Commis. sion. At, the age of 73 he retired from this post and joined the staff of the National Academy of Sciences to assist with its programme for scholars from overseas. His worldwide contacts were of obvious importance in this function.

Colby was extremely modest and therefore known only to those he met personally; most of these became his friends. It is, however, unfortunate that his modesty prevented him from writing down his memoirs of the early part of his life, for with his death the last link with physics at the beginning of the twentieth century has vanished.

\author{
Sir Archibald Day
}

Vice-Admiral Sir Arohibald Day, KBE, CB, DSO, former Hydrographer of the Navy, died at Dover on July 17.

He first went to sea with the Royal Navy in 1914, at the age of fifteen, and served at sea throughout the First World War. He volunteered for the hydrographic surveying specialization in 1920, joining first HMS Endeavour for surveys on the Egyptian coast, and then served continuously in surveying ships. From 1937 he was Superintendent of Charts in the Hydrographic Department, commissioning a new surveying ship, HMS Scott, in February 1939 for surveys off the east coast of England.

In 1940, Day played a major part in organizing the Dunkirk evacuation. During 1943 and 1944 he held the post of Assistant Hydrographer while charts were being prepared for the Sicilian and Normandy landings; later he led a combined surveying and minesweeping flotilla which opened up the Malay and East Indies ports. He was awarded the DSO for his work in clearing and marking the Rangoon River before the assault on the city.

He returned to normal peacetime surveying as Assistant Hydrographer, and, in 1950, took over from Vice-Admiral Sir Guy Wyatt as Hydrographer of the Navy, a post which he held with distinction for five years. Wyatt had realized the importance to the Fleet of studying the oceans as a whole rather than from the purely bathymetric standpoint, and once again seagoing scientists were welcome on board HM surveying ships. This policy was carried forward by Day, largely in collaboration with the Department of Geodesy and Geophysics at Cambridge, including the completion of a modern world-wide Challenger voyage whose scientists were largely engaged in seismic work in the deep oceans. Cooperation between naval surveying officers and military and civilian oceanographers has continued to grow until today it is accepted as routine.

In 1956, Day was appointed coordinator of operations for the International Geophysical Year, a post he occupied in Brussels for three years. Day could well have been a diplomat, for with great charm and tact he nearly always got his own way without offending anyone. These qualities, together with his keen interest in promoting scientific work at sea, fitted him uniquely for his IGY post, and he travelled relentlessly in his efforts to promote harmonious and cooperative international work among marine scientists.

More recently he prepared a detailed and well documented history of the Hydrographic Department from 1795-1919 (HMSO, 1967). This book provides a great wealth of fact about the development of the department for which he worked for much of his life.

\title{
Announcements
}

\section{University News}

Dr A. P. McE. Forrest has been appointed to the Regius chair of clinical surgery in the University of Edinburgh, in succession to Sir John Bruce who retires on September 30.
Professor R. M. Shackleton, professor of geology and director of the Research Institute of African Geology, University of Leeds, is to visit the Halle Selassie I University, Addis Ababa, as Royal Society Leverhulme visiting professor. 